9. Kulikova, L. I. The Interrelation between the Professional Judgment of an accountant and the Quality of Financial Reporting [Text] L. I. Kulikova, L. L. Grigoryeva, A. R. Gubaidullina // Mediterranean Journal of Social Sciences. - 2014. - Vol. 5, № 24. P. 61-64. doi:10.5901/mjss.2014.v5n24p61

10. Kulikova, L. I. Professional'noe suzhdenie buhgaltera kak instrument formirovaniia finansovoi otchetnosti [Text]: Monograph / L. I. Kulikova, A. R. Gubaidullina. - Moscow: Prospekt, 2015. - 128 p.

11. Petrova, I. Vplyv profesiinoho sudzhennia bukhhaltera na oblikovu polityku pidpryiemstva [Text] / I. Petrova, N. Piskunova // Bulletin of Student Scientific Society. - 2012. - Vol. 2, № 2. P. 267-271

12. Pushkar, M. S. Teoriia i praktyka formuvannia oblikovoi polityky [Text]: Monograph / M. S. Pushkar, M. T. Shchyrba. Ternopil: Kart-blansh, 2009. - 260 p.

13. Synytsia, T. V. Neobkhidnist ta ymovirni ryzyky zastosuvannia profesiinoho sudzhennia bukhhaltera v oblikovii praktytsi [Text] / T. V. Synytsia // Zbirnyk naukovykh prats Kharkivskoho natsionalnoho pedahohichnoho universytetu im. S. H. Skovorody. Ekonomika. - 2013. - Vol. 13. - P. 208-212

14. Smirnova, E. A. Accountant's professional opinion: concept, matter and content [Text] / E. A. Smirnova // Theory and practice of social development. - 2012. - № 10. - P. 291-294.

15. Stafievskaya, M. V. Risk accounting in commercial organizations [Text] / M. V. Stafievskaya // International Accounting. - 2014. - № 35 (329). - P. 16-29.

16. Tuyakova, Z. S. Classification of professional opinion as a modern instrument of accounting [Text] / Z. S. Tuyakova, E. V. Satalkina // Bulletin of the State University Orenburg. - 2010. № 1 (107). - P. 90-97.

17. Yukhymenko-Nazarchuk, I. A. Osoblyvosti zastosuvannia profesiinoho sudzhennia bukhhaltera $\mathrm{v}$ umovakh formuvannia oblikovoi polityky pidpryiemstva: instytutsiinyi aspekt [Text] / I. A. Yukhymenko-Nazaruk // Problemy teorii ta metodolohi bukhhalterskoho obliku, kontroliu i analizu. Ser.: Bukhhalterskyi oblik, kontrol i analiz. - 2014. - Vol. 2 (29). - P. 195-206

18. Boyko, K. Disclosure of Non-Financial Information in Corporate Social Reporting as a Strategy for Improving Management Effectiveness [Text] / K. Boyko, I. Derun // Journal of International Studies. - 2016. - Vol. 9, № 3. - P. 159-177.

19. Derun, I. Risk identification in the company's accounting system [Текст] / I. Derun // Economic Annals-XXI. - 2016. Vol. 159, № 5-6. - P. 97-100. doi:10.21003/ea.v159-21

20. G4 Sustainability Reporting Guidelines [Electronic resource]. Available at: \www/URL: https://www.globalreporting.org/ resourcelibrary/GRIG4-Part1-Reporting-Principles-and-Standard-Disclosures.pdf. - 26.02.2017

\section{УСОВЕРШЕНСТВОВАНИЕ СУЩНОСТИ ИНСТИТУТА ЛРОФЕССИОНАЛЬНОГО СУЖДЕНИЯ В БУХГАЛТЕРСКОМ УЧЕТЕ УКРАИНЫ}

Исследовано сущность профессионального суждения в Международных стандартах финансовой отчетности и украинском законодательстве в сфере бухгалтерского учета. Проведен критический анализ научных подходов украинских и иностранных бухгалтеров к дефиниции «профессиональное суждение бухгалтера». Предложен авторский подход к пониманию профессионального суждения бухгалтера, что обусловлено рядом новых вызовов в украинской системе бухгалтерского учета.

ключевые слова: Международные стандарты финансовой отчетности, Международные стандарты аудита, профессиональное суждение бухгалтера, условие неопределенности.

Derun Ivan, PhD, Assistant Professor, Department of Accounting and Audit, Taras Shevchenko National University of Kyiv, Ukraine, e-mail: ivanderun0601@gmail.com, ORCID: http://orcid.org/00000002-8115-8701

\section{Zakharchenko N., Maslii N., Kostolonova L.}

\title{
SEOUENCE OF FORMATION OF THE PORTFOLIO OF HIGH-TECH PROJECTS
}

Розглянуті ключові етапи формування портфеля високотехнологічних проектів на підприємстві на основі сучасних теоретичних підходів до розуміння $і$ обгрунтування місия і ролі інновацій в основній діяльності організації. Розглянуто особливості високотехнологічних проектів з метою мінімізаціі проектних ризиків і оптимізацї параметрів ефективності проектів. Представлені елементи механізму формування високотехнологічного портфеля підприємства.

Ключові слова: портфель високотехнологічних проектів, мінімізація проектних ризиків, оптимізація параметрів ефективності проектів.

\section{Introduction}

Scientific and technological progress, recognized all over the world as the most important factor in economic development, more and more often associated with the concept of high-tech process. This is a unique process that combines science, technology, economics, entrepreneurship and management. It consists in obtaining innovation and extends from the birth of the idea to its commercialization in the form of high-tech processes.

\section{The object of research and its technological audit}

During realization of mechanism of highly technological portfolio of enterprise construction it is necessary to consider some features of highly technological projects. Seeming similarity of methods of the project financing and procedure of the financial analysis required for the estimation of large capital investments and selection of scientific and technical projects can lead to supposition 
about adequacy and identity of the applied procedures. At the same time between these two projects there are important distinctions. Available financial information on capital investments for construction of new industrial facilities is much more reliable than most simple of high-tech projects, especially in the early stages.

There is difference significantly greater uncertainty and risk high-tech projects have the advantage that they can be terminated with little financial loss at the early stages of development. Also noteworthy is the factor of limited information in the selection of high-tech projects, compared to investment in high-tech projects are much more likely to encounter inadequate information. It seems extremely difficult to correlate the opinions of independent experts. High-tech projects differ not only by multicriteriality and a significant degree of uncertainty and risks but also qualitative assessment. That is why we need a special procedure to establish integrated criteria of efficiency and optimal compliance efforts the result. Of course, the most successful will be the project which satisfies the greatest number of criteria. In this regard, it is very difficult to choose a variant of the proposed high-tech projects, therefore, to minimize project risks and optimize performance parameters of the project and should be used the mechanism of formation of high-tech portfolio.

High-tech portfolio should contain a variety of projects: large and small, long and short term, different in purpose and principles of the realization that is necessary for optimum innovation with simultaneous high productivity of financial and economic indicators, as well as for the successful implementation of innovative strategies enterprise. In this regard, the portfolio content should be audited frequently enough, the revision and updating.

The final step of the formation mechanism of high-tech portfolio of businesses is a rational division of innovation for innovations that are introduced and innovations that are being developed for sale.

\section{The aim and objectives of research}

The study is aimed to analyze the key stages of the high-tech projects formation at the enterprises in the current economic situation.

To achieve the research objectives the following scientific objectives are defined:

1. To consider and to analyze the characteristics of high-tech projects.

2. To conduct a comprehensive analysis of stages of formation of a portfolio of high-tech projects in the enterprise.

3. To analyze the financing of scientific activity in Ukraine.

4. To offer recommendations for the improvement of the mechanism of formation of high-tech projects in the framework of the chosen strategy of the enterprise.

\section{Research of existing solutions of the problem}

Innovation experts studied a wide variety of disciplines sociologists, economists, historians, researchers, administrative processes. The research study is devoted to high-tech processes are very few works in which, moreover, reflects the specificity little transformational economy of Ukraine. The procedure for selection, approval and registration of high-tech projects, as well as project proposals subject to state support presented in [1-3]. The authors in [4] were examined ways to improve implementation of high-tech projects in industry. The solutions to the problems that arise in the process of implementing business innovations are presented in [5]. The mechanism of formation and the effective management of the projects are considered in [6]. The authors [7] investigated scientifically-methodical bases of pre-planning evaluation. In [8] the development of science and technology and the level of research funding is analyzed. The implementation project analysis of innovation and investment activity is presented in [9]. However, in modern conditions of managing the functioning of enterprise innovation potential is carried out in the framework of the constantly changing conditions that determines the need for continuous improvement of programs of high-tech activities.

\section{Methods of research}

To solve the set tasks were used the following methods: analysis and synthesis, logical generalizations, analogies, comparative mapping, graphic-analytical method, statistical method.

\section{Research results}

In everyday practice, usually identify the concept of innovation and novation, which is understandable. Any inventions, new phenomena, services or methods will be recognized only when they are taken to the spread (commercialization), and in a new capacity, they will act as innovation.

The transition from one quality to another requires resource costs (energy, time, finances and so on). The process of transfer of novation - innovation also requires the cost of various resources, the main of which is the investment and time.

In the high-tech sector long-term and medium-term investments play a dominant role, as a high-tech process lasts an average of 3-5 years or more. In conditions of economic crisis in Ukraine public sources of funding are drastically reduced $[2,3]$.

The total volume of investments in fixed capital industry, the share of investments in the innovative renewal of fixed capital is approximately $1.5 \%$ of total investments in the industry of Ukraine. To conduct a full-scale modernization of the economy by 2020 , this figure should be increased more than a 6 -fold, to a minimum of $9 \%$ of the necessary investment in the growth of high-tech activity of industrial enterprises. An important trend in the field of efficient investment of high-tech activities have the practical ability of single large-scale investments in order to achieve an elongated effect increasing investment in industrial activities. This means that it can effectively use the mechanism of public programs to perform the tasks of modernization of high-tech sector of Ukraine. Let's note the precipitous decline in 2013 in funding the activities of Ukrainian high-tech industries (Table 1) on the part of foreign investors (56.9 million USD in 2013 against 2.4114 billion UAH in 2012 that even below the level of 2001). 
Table 1

Sources of financing of technological innovation in Ukraine, mln UAH

\begin{tabular}{|c|c|c|c|c|}
\hline Year & Dwn & $\begin{array}{c}\text { State } \\
\text { Budget }\end{array}$ & $\begin{array}{c}\text { Foreign } \\
\text { investments }\end{array}$ & $\begin{array}{c}\text { Other } \\
\text { sources }\end{array}$ \\
\hline 2000 & 1399.3 & 7.7 & 133.1 & 217.0 \\
\hline 2001 & 1654.0 & 55.8 & 58.5 & 203.1 \\
\hline 2009 & 5169.4 & 127.0 & 1512.9 & 1140.6 \\
\hline 2012 & 4775.2 & 87.0 & 2411.4 & 771.9 \\
\hline 2013 & 7585.6 & 149.2 & 56.9 & 994.7 \\
\hline 2014 & 7335.9 & 224.3 & 994.8 & 345.8 \\
\hline
\end{tabular}

Note: The Global Competitiveness Report 2015-2016 [8].

Decisive importance of state support of innovation in the economic dynamics of the market economic system is fully justified by many researchers of different countries [6]. However, the use of innovation as a factor for economic growth in enterprises and firms associated with two major challenges: the limitations in financing hightech activities and complexity of innovation management, designed to take away from all the innovations varieties most attractive to investors, and the most beneficial for the company to strengthen its position in market [4].

Innovation must have a degree of novelty to counter the risks associated with it. There is the problem of determining the stage where innovation reaches the novelty that are necessaryand recognized bythe market to use the earliest possibility of using venture capital.

The first sign of such state of innovation is the clarity of its practical benefits, consumer properties, among which must be new, non-traditional, more attractive in comparison with competitors. This is the first sign of the possibility of using venture capital [7].

But the center of gravity of the use of venture capital has on the commercial performance of the implementation of the innovation.

During 2000-2013 (except the crisis of 2009 and postcrisis 2010) there was a trend - a steady increase in the amount of total costs of industrial enterprises for the individual enterprises of high-tech activity (Fig. 1), (but it is only at current prices), but this amount to acquire new technologies on average only $3-4 \%$, and the purchase of machinery, equipment, facilities and other fixed assets - 60-70\%, indicating that there is a threat their own high-tech base.

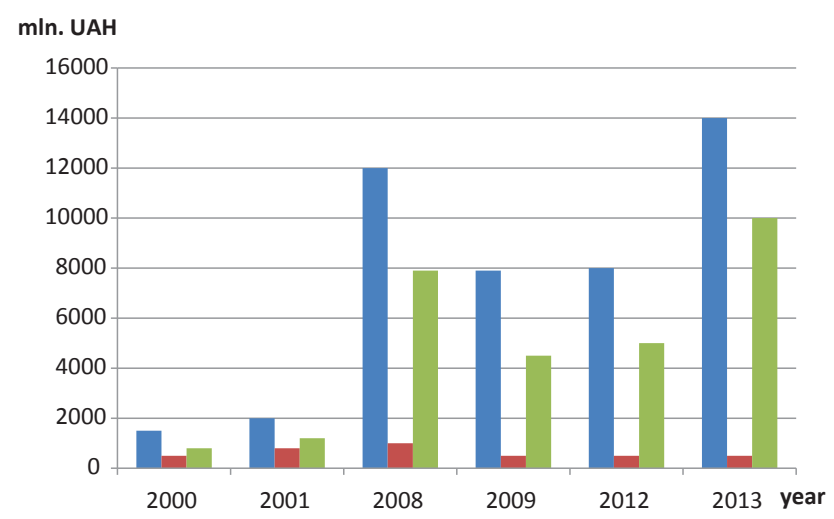

Fig. 1. The distribution of total costs in certain areas of high-tech activities (based on the data: "Science and innovation activity in Ukraine» for the relevant years)
In the publications of many economists of Ukraine [4, 6, 7], and other countries can be found the opinion that only innovation in the field of so-called high-tech because of its radical novelty can be considered as an object of innovative financing venture capital. This approach denies in the practice of many countries. Orientation of venture capital only on high-tech projects, of course, would prevent many of the financing of innovative projects relating to the reproduction of simulation innovation and innovations with a low degree of novelty, but has great potential widespread commercial success [5].

So, for venture capital are important, not just the results of scientific-technical and high-tech activities, but only those that have a high chance of recognition of a large number of consumers in the market.

In principle, funding innovation through venture capital can be used in all the above types of innovation.

The most important essential characteristic of hightech project is, in our opinion, its focus for a specific innovation or complex innovations in the form of new products, technology, organizational structure, management practices, etc., have certain characteristics at the same time (parameters). Other high-tech activities are organized in a certain way as a project but not directly related and doesn't lead directly to innovation, in our opinion, and should not be considered as high-tech projects.

In modern conditions of managing the operation of the innovative capacity of the organization is carried out within a constantly changing environment, which necessitates continuous improvement of high-tech activity programs.

Under these conditions, the innovative potential of the enterprise management system must be flexible enough to allow the necessary modifications. Consequently, the hightech enterprise portfolio can consist of a variety of large and small projects and close to the end and beginning. However, each project requires the allocation of scarce resources, depending on its characteristics (complexity, labor intensity, etc.). In this connection, high-tech projects need to rank for their effective use.

Based on this, we believe that a high-tech enterprise portfolio should have some contours - to be, if possible, a stable to the optimal realization of innovative potential. Number of high-tech projects in the portfolio at any given time should depend on their size, which is measured a total investment of resources needed for development, and the cost of implementation of the project. The number of high-tech projects in the portfolio must be determined by the ratio of high-tech activities budget for a certain period of time to the average cost per project. Based on this, companies need to decide how many high-tech projects at the same time can be effectively managed; or to focus on a number of projects, or to distribute the resources available to a larger number of projects.

It should be noted that the high-tech portfolio, consisting mainly of large-scale projects, more risky compared to the portfolio, where resources are distributed between minor projects.

At the same time it must be remembered that the small projects that require relatively low cost of high-tech activities are typically implemented in new products, have modest potential in terms of sales and, consequently, the possibility of making a profit. Small projects portfolio could lead to a uniform stream of innovations, most of which have limited market potential, which is undesirable from the standpoint of the product range formed by enterprises for sale. 
It is important to note that, considering one or the other high-tech projects for inclusion in the portfolio, it is necessary to consider the possible quality of its management and the consequences of redistribution of costs for projects. Consequently, the portfolio formation should include carrying out work with the potential users of the results of innovation. Also, the development of the mechanism of formation of high-tech enterprise portfolio must take into account that the current situation prevailing in the Ukrainian enterprises, it is very difficult, sometimes even impossible, to accurately predict the demand for innovative products, i. e. there is uncertainty in demand.

The next element of the mechanism of formation of high-tech enterprise portfolio project financing is hightech activities. However, it should be noted that this is certainly grow and project financial risks and consequently the requirements for high-tech projects expert judgment. These issues need to be addressed both from the methodological, and practical and organizational plans, since today is difficult to find not only the lender, but also independent consultants to assess the suitability and the risk of obsolescence of products.

It is important to pay attention to the possible diversification of highly technological projects and outsourcing. Let's consider, for example, at the time (the beginning of the 1980s.) IBM has decided to transfer the production of micro-processes for their computers to the Intel company and the production of operating systems - developed by Microsoft [5]. The very same IBM was to focus on the fact that it knew how to do best - the development, collection and promotion of the personal computer market. From the point of view of the company's development history, these solutions are presented fairly appropriate.

And Intel and Microsoft were previously unknown company with minimal profits. Thus, IBM was able to dramatically reduce the development time and the launch of new computers. Still, transferring part of its produc- tion, the IBM launched the business two other companies, which subsequently began to receive the highest profits in the industry, and because they could get itself IBM.

IBM and other companies have shown for viewing, of course - that the division of highly technological (HT) projects and basic side can result in serious, even detailed errors. It is not always necessary to be equal to what the company does best at the moment. Instead, it need to think how the production is necessary to master today, and how - in the future to improve the HT product in a direction important for consumers.

We must consider the following: consumers will get the goods only if with the help of solving important problems for themselves. But these solutions can vary from the two conditions shown in Fig. 2: the product may not be sufficient quality or, conversely, too qualitative. We come to the conclusion that, if the product is not good enough, the company is more profitable to integrate all production at home. Outsourcing - or specialization and disintegration opposite expedient if the product becomes too high quality.

To remember this last statement, it should consider the technical concept of «interdependence» and «modularity» and to show their importance to architecture of HT products.

Architecture of HT product defines its components and their interactions: in general, they are suitable for each other, so as a result, the functionality has been achieved, for which the product was designed. Architecture of HT products are interdependent, if at least one of its components cannot be created separately from the other, if the development and production depends on how developed and other components are manufactured. If the company wants to develop and create a product component, and thus in any of its contact zones might appear unpredictable relationship, then it is necessary to develop and simultaneously create both components. Interdependent architecture optimizes the properties of products in terms of its functionality and reliability.

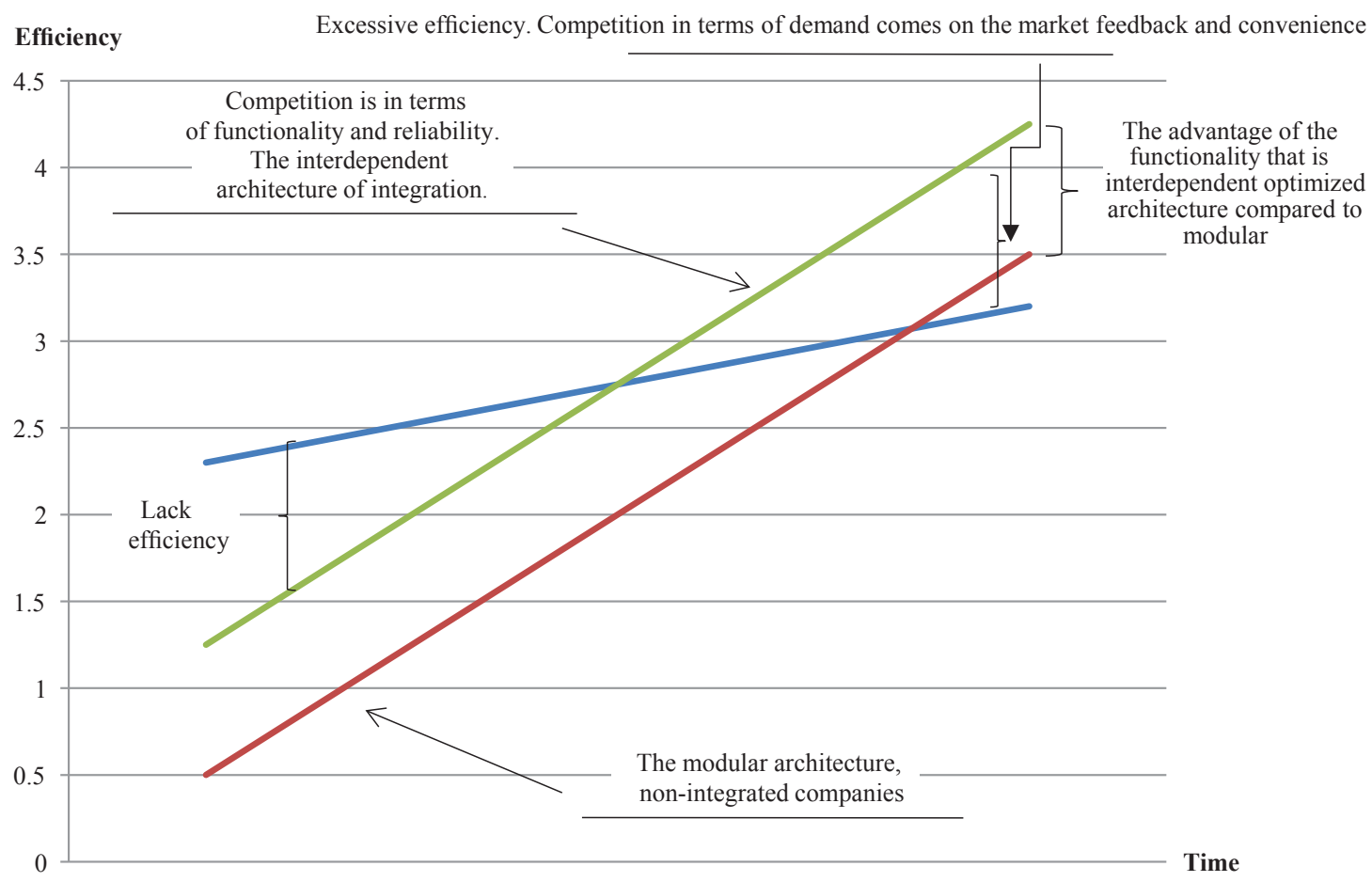

Fig. 2. Architecture of HT products and integration (compiled on the basis of [5]) 
On the contrary, the modular contact zone is not unexpected relationships between contacts products or stages in the value chain. Modular components fit together and work together for the clear and well-defined rules. Modular components can be developed independent working groups or in different companies, managed from a central location.

Based on the above, it should be considered some of the features of high-tech projects.

Featuring a much greater uncertainty and risk, high-tech projects have the advantage that they can be terminated at small financial losses in the early stages of development.

Thus, it is possible to distinguish three main phases of the sequence of formation of a high-tech projects' portfolio:

1) search for potential projects;

2) formulation of initial assessment and selection of projects for inclusion in the portfolio;

3) financial analysis and final selection of projects in the portfolio.

A second factor that makes these highly technological projects so special is that they are often the foundation or platform for a new product line or an entirely new business. In short, highly technological projects are important to profitability in that they help to de-commoditize the business's product offerings [10]. They are the breakthroughs, disruptive technologies and radical innovations that create the huge growth opportunities and superlative profits [11].

Finally, the criteria used to rate and prioritize development projects as found in most company's stage-and-gate development processes again assume projects that are fairly well-defined [12]. For example, an Industrial Research Institute study revealed that 78 percent of businesses rely heavily on financial criteria to select projects: criteria such as projected annual profits, net present value (NPV) and expected sales [13].

Making the resource commitment decisions for highly technological projects, especially in the early stages, is problematic for many companies. Clearly, traditional tools, such as financial analysis and profit criteria, are not too useful. In highly technological projects with much uncertainties, the level of uncertainty is so great that numerical estimates of expected sales, costs, investment, and profits are likely to be grossly in error [14]. Indeed there is considerable evidence that businesses that rely strictly on financial tools and criteria to select projects end up with the lowest-value development portfolios [15]. Our evaluation tools assume a level of precision far beyond the quality of the data available! Not surprisingly, this executive's financial evaluation tool tended to favor predictable and close-to-home projectsat the expense of technology development projects. Best performers adopt a combination of evaluation techniques and criteria for making decisions on highly technological projects [16].

And finally, the latest statistics. In the structure of financing of high-tech activity, the share of the state: if in 2013 it amounted to $0.3 \%$ of the total financing of high-tech activities in $2014-4.5 \%$. At one company in 2014 it had an average of 0.28 million UAH of budget expenditures (in $2013-0.02$ million USD) [7]. Most volume of budget financing of high-tech projects in 2014 have been allocated to the production of basic pharmaceutical products and pharmaceutical preparations (on average - 35.46 million USD, in 2013 - 14.99 million USD), as well as weapons and ammunition [8].
Spending on high-tech activities in Ukraine increased annually in absolute intention, but their share in the GDP is less than $1 \%$. It should be remembered that the Law of Ukraine «On science and scientific and technical activity» in accordance with the state of science funding in the amount of $1.7 \%$ of GDP. In 2014, research intensity of GDP was $0.66 \%$ - the lowest since 2005 , which deprived science's ability to perform the function of maintaining the required rate of scientific and technological progress. The share of public funds in the financing of science in 2014 was equal to $0.26 \%$ of GDP (in 2013 - $0.33 \%$ ) [8].

\section{SWOT analysis of research results}

Strengths. Strengths of the study is a comprehensive analysis of stages of formation of a high-tech projects' portfolio in the enterprise and offering recommendations for building a sequence of elements of the mechanism of formation of high-tech projects to minimize project risks and optimize performance parameters of the projects.

Weaknesses. The weak side is that the selection of hightech projects compared with investment, there is limited information, as in high-tech projects much more can be faced with inadequate information. High-tech projects have not only multicriterial but also qualitative assessment. It is therefore necessary to establish a special procedure for the integral performance criteria and optimal matching of the efforts of the results. Of course, the most successful will be a project that satisfies the greatest number of the criteria. In this regard, it is difficult to select an option from the proposed high-tech projects, so to minimize project risk and optimize project performance parameters and should be applied the mechanism of formation of hightech portfolio.

Opportunities. Opportunities for the further research is the experience of foreign countries in the formation of enterprise's high-tech portfolio. World experience showed examples of successful companies that were involved in the development of high-tech technologies and their commercialization. However, some companies remained only one name, and others successfully continue their economic activities. This phenomenon, among other things, is due to the proper selection and maintenance of the mechanism of formation of high-tech projects to minimize project risks and optimize performance parameters of the projects.

Threats. Threats to the research results is underfunding by the state of scientific activity in Ukraine. At the domestic legislative level, it is stipulated that the financing of science should be implemented at the level of not less than $1.7 \%$ of GDP.At the same time, in the world this indicator makes $3 \%$. At the same time, in recent years, the value of this indicator for Ukraine does not exceed even $0.5 \%$. That is why, in addition to increasing spending on research and development, it is necessary to search for new sources of financing scientific and scientific-technical works. An important step to financial support of scientific research in Ukraine is attracting and stimulating the business sector in the innovation process. It is also important to involve in the process of investment in high-tech projects, financial resources of Bank and non-Bank segment of the market. Financial institutions that participate in this funding should receive additional incentives. Thus, if the government does not change its attitude to the financial support of the research, it will continue to lose 
competitive position of the economy. The underfunding of scientific research leads to the leakage of the scientific potential abroad and puts the country in the category of underdeveloped. Underestimation of the role of scientific research hinders the development of Ukraine.

\section{Conclusions}

1. Conducted analysis of high-tech projects allowed to define that high-tech project constitutes a fully justified list of innovations that was acquired as well as created by the enterprises and that is subjected to the implementation and realization at this enterprise. High-tech projects vary not only by multi-criteria abilities and meaningful grades of risks but also by the qualitative assessments Of course, the most successful will be the project which satisfies the greatest number of criteria. In this regard, it is very difficult to choose a variant of the proposed high-tech projects, therefore, to minimize project risks and optimize performance parameters of the project and should be used the mechanism of formation of high-tech portfolio.

2. Conducted comprehensive analysis of formation sequence of a portfolio of high-tech projects in the enterprise consists of finding potential projects, formulation, primary evaluation and selection of projects for inclusion in the portfolio, financial analysis and final selection of projects in the portfolio.

3. Based on this analysis, the current state of science funding in Ukraine is quite disappointing because there is a tendency to decrease in volumes of financing of scientific and scientific-technical works in comparison with the number of countries, which indicates that the backlog of Ukraine in innovative development. In developed countries the funding of research has received considerable attention. For example, the leading countries with the highest level of expenditures on research activities are: Israel (4.74\%), Sweden (3.63\%), Finland (3.47\%), Japan (3.39\%), South Korea (3.22\%), USA (2.68\%). According to the world economic forum «The Global Competitiveness Report», Ukraine takes the 78th place among Western European countries on the criterion of investment of financial resources in the research and development underlying the development and full implementation of innovation.

4. The proposed recommendations are that a portfolio of high-tech projects can be presented as a typical model for making innovation investment decisions. The process of such decision-making is inextricably linked with the internal environment of the enterprise in which it arises and flows. Therefore, all innovative-investment projects potentially considered for inclusion in the portfolio will not conflict with the strategic plans of the company, because they determine the General direction of its activities. Relationship of strategic planning and innovation-investment activity of the enterprise consists in foresaid. Portfolio approach to managing high-tech projects allows companies to develop a balanced portfolio of projects, thereby more effectively to innovate, to adapt quickly to changing economic conditions and to respond adequately to the risks inevitably accompanying the activities of the innovationactive companies. Application of methodology of project portfolio management allows to determine the degree of conformity of investment projects with the strategic goals of the company. Using the methods of portfolio company, management can more efficiently assess the risks of projects, the benefits derived from their implementation, to monitor implementation of projects and to predict the development of the company. Basis of this, the main conclusion is the fact that the use of formation mechanism of high-tech portfolio of the company is one of the elements of estimation of innovative potential and determines the strategy of high-tech development in the established economy.

\section{References}

1. Pro pidhotovku ta realizatsiiu investytsiinykh proektiv za pryntsypom «yedynoho vikna» [Electronic resource]: Law of Ukraine from 21.10.2010№ 2623-VI. - Available at: \www/ URL: http://zakon3.rada.gov.ua/laws/show/2623-17

2. Pro zatverdzhennia Poriadku vidboru, skhvalennia i reiestratsii investytsiinykh proektiv u priorytetnykh haluziakh ekonomiky ta vymoh do takykh proektiv [Electronic resource]: Resolution of the Cabinet of Ukraine from August 14, 2013 № 715. Available at: \www/URL: http://www.kmu.gov.ua/control/uk/ cardnpd? docid $=246738634$

3. Pro zatverdzhennia Poriadku vidboru proektnykh (investytsiinykh) propozytsii ta investytsiinykh proektiv, dlia rozroblennia abo realizatsii yakykh nadaietsia derzhavna pidtrymka [Electronic resource]: Resolution of the Cabinet of Ukraine from November 13, 2013 № 835. - Available at: \www/URL: http:// zakon2.rada.gov.ua/laws/show/en/835-2013-п

4. Zaharchenko, V. Sovershenstvovanie realizatsii proektov v vysokotehnologichnoi otrasli [Text]: Monograph / V. Zaharchenko, L. Glushchenko. - Vinnitsa: Izdatel'sko-poligraficheskaia Rabota, 2013. - $152 \mathrm{p}$.

5. Christensen, C. M. The Innovator's Solution: Creating and Sustaining Successful Growth [Text] / C. M. Christensen, M. E. Raynor. - Harvard Business Review Press, 2013. - 320 p.

6. Mazur, I. I. Upravlenie proektami [Text]: Handbook / I. I. Mazur, V. D. Shapiro. - Moscow: Sredniaia shkola, 2001. - 875 p.

7. Zaharchenko, V. I. Nauchnye i metodologicheskie osnovy predplanovoi otsenki innovatsionnyh investitsionnyh proektov: podschet [Text]: Monograph / ed. by V. I. Zaharchenko. Odessa: Atlas, 2015. - 104 p.

8. The Global Competitiveness Report 2015-2016 [Electronic resource]. - Available at: \www/URL: http://reports.weforum.org/ global-competitiveness-report-2015-2016/

9. Yakovlev, A. I. Proektnyi analiz investitsii i innovatsii [Text] / A. I. Yakovlev. - Kharkiv: Biznes-inform, 1999. - $114 \mathrm{p}$

10. Clayton, M. C. The Innovator's Dilemma: When New Technologies Cause Great Firms to Fail [Text] / M. C. Clayton. Harvard Business School Press, 1997. - 179 p.

11. Cooper, R. G. Benchmarking Best Practices Performance Results and the Role of Senior Management [Electronic resource] / R. G. Cooper, S. J. Edgett. - Product Development Institute Inc., 2003. - Available at: \www/URL: https://www.stage-gate. net/pdi/pc/downloads/8\%20Practices\%20of\%20Top\%20Performing\%20Innovation\%20Leaders.pdf

12. Doorasamy, M. Product portfolio management for new product development [Text] / M. Doorasamy // Problems and Perspectives in Management. - 2015 - Vol. 13, № 4 - P. 102-114.

13. Clark, J. Innovation and competitiveness [Text]: A review J. Clark, K. Guy // Technology Analysis \& Strategic Management. - 1998. - Vol. 10, № 3. - P. 363-395. doi:10.1080/ 09537329808524322

14. Movery, D. The Practice of the Technology Police [Text] D. Movery // In Handbook of the Economics of Innovation and Technological Change. - Oxford: Blackwell Handbook in Economics, 1995. - 382 p.

15. Perloff, J. Modern Industrial Organization [Text] / J. Perloff, K. van Veld. - Harper Collin's, 1994. - 973 p.

16. Peters, T. The Circle of Innovation [Text] / T. Peters. - Coronet Books, 1998. - 579 p.

\section{ПОСЛЕДОВАТЕЛЬНОСТЬ ФОРМИРОВАНИЯ ЛОРТФЕЛЯ ВЫСОКОТЕХНОЛОГИЧЕСКИХ ПРОЕКТОВ}

Рассмотрены ключевые этапы формирования портфеля высокотехнологических проектов на предприятии на основе современных теоретических подходов к пониманию и обоснованию места и роли инноваций в основной деятельности 
организации. Рассмотрено особенности высокотехнологических проектов с целью минимизации проектных рисков и оптимизации параметров эффективности проектов. Представлены элементы механизма формирования высокотехнологического портфеля предприятия.

Ключевые слова: портфель высокотехнологичных проектов, минимизация проектных рисков, оптимизация параметров эффективности проектов.

Zakharchenko Natalia, PhD, Associate Professor, Department of Economics and Modeling of Market Relations, Odessa I. I. Mech- nikov National University, Ukraine, e-mail: vizach@mail.ru, ORCID: https://orcid.org/0000-0002-9895-531X

Maslii Natalia, PhD, Associate Professor, Department of Economics and Modeling of Market Relations, Odessa I. I. Mechnikov National University, Ukraine, e-mail: masliy.natalia@gmail.com, ORCID: https://orcid.org/0000-0002-3472-5646

Kostolonova Luydmila, Senior Lecturer, Department of Economics and Modeling of Market Relations, Odessa I. I. Mechnikov National University, Ukraine, e-mail: kostolonova@mail.ru, ORCID: https:// orcid.org/0000-0002-8122-0907

\section{Kasych A., Vochozka M., Buhas N.}

\section{INVESTIGATION OF MODERN APPROACHES TO EFFICIENCY ANALYSIS OF THE FUNCTIONING OF CORPORATE INNOVATION SYSTEMS}

Проведено дослідження сучасних підходів до дослідження ефективності функціонування корпоративних інновачійних систем, основними серед яких визначено системний, стратегічний та комплексний підходи. Запропоновано методику аналізу інноваційної діяльності та процедуру ї інкорпорації в систему управління інноващійними процесами. Визначено функціональні сфери, пов'язані зі створенням інноващій. Розроблено набір показників і критеріӥв для проведення моніторингу всіх підсистем, що дозволить визначити реальний стан справ у секторі продукування інновацій.

Ключові слова: інноващійна активність, інноващійна політика, корпоративні інноваційні системи, системний підхід.

\section{Introduction}

The application of the system approach to the study of problems of innovation development led to the formation of the concept of innovation systems, which are traditionally explored at the regional and national levels. However, the innovation activity of enterprise is the basis for the effectiveness of the functioning of innovation systems at any level, and accordingly its study should be viewed in the overall complex of management tasks that are strategically important for the formation of the competitive advantages of modern enterprise.

A number of international institutions and agencies annually identify global and industry leaders in the field of innovation. The innovation activity of these enterprises can and should be a guide for the development of others, and therefore requires research in the context of creating the conditions for enhancing and improving the effectiveness of the innovation sector. Especially these issues are important for Ukrainian enterprises, which innovation activities require the introduction of modern management methods.

\section{The object of research and its technological audit}

As an important indicator and condition of innovation the indicator of innovation costs are used, but innovation activity is a complex process, and therefore requires a comprehensive study that would provide an understanding of the nature and patterns of innovation development at the micro level. That is why the development of the methodology for analyzing innovation activities and their incorporation into the management system of innovation processes is topical and has practical importance. The application of the theory of innovation systems in this case will make it possible to present the subject of research in the form of clear algorithms and procedures adapted to the needs of practical implementation.

At Ukrainian enterprises, innovations are still financed by a residual principle, innovation processes are managed on an unsystematic basis, and thus organizational issues and their methodological support require precise regulation.

\section{The aim and objectives of research}

The aim of research is to develop the main stages of the methodology for analyzing the innovation activity of enterprises, which will allow to create a detailed information base of management decisions in the field of innovation in the context of providing innovation processes in Ukrainian enterprises with signs of systemic and sustainability.

To achieve this aim, the following objectives are identified:

1. To identify the main approaches to the study of innovation processes and to ensure their transformation into a practical plane. 